\title{
RESEARCH PAPER \\ CHIEFS, CHANGING TRUST RELATIONS AND LAND USE PLANNING IN GHANA
}

\author{
E. Yeboah and R. A. Oppong \\ College of Art and Built Environment, KNUST, Kumasi \\ E-mail:eryckyeboah@yahoo.com; e.yeboah.cap@knust.edu.gh
}

\begin{abstract}
In Ghana, both statutes and customs designate chiefs as trustees of customary lands. Based on evidence from four case study areas, the study establishes that, some chiefs are redefining their roles as trustees and are increasingly becoming the principal beneficiaries of revenue that accrue from granting of community lands. This drives chiefs to alter land use plans or engage unqualified people to prepare defective 'land use plans', that become the basis for guiding the growth of human settlements. These practices contribute to the poor state of planning delivery. Based on the findings, the study recommends that strengthening the capacity of state planning institutions and empowering communities to demand accountability from chiefs are crucial in the quest to improve land use planning delivery in Ghana.
\end{abstract}

Keywords: Accountability, customary land tenure, chiefs, trusteeship, land use planning

\section{INTRODUCTION}

Ghana's population is experiencing a rapid annual growth rate of $2.26 \%$, which mirrors the continental trend (UN-DESA, 2013). Accordingly, urbanization is rife and continues to pose challenges for planning delivery.

The essence of land use planning is to ensure an orderly spatial development. As Ratcliffe and Stubbs (1996) argue, planning is primarily concerned with managing the layout of the environment by providing the right site at the right time, in the right place for the right people. However, the institutions charged with the responsibility for land use planning have done little to exert their expected prescriptive influence in the country. Accordingly, the growth of human settlements hardly ever proceeds on planned and sustainable basis. Ubink and Quan (2008:202) have described physical development in Ghana as 'haphazard'. It is therefore not surprising that the normal procedure of planning, servicing, building and occupation has now been mixed up in the sequence of occupation-building-servicing and planning without any reference to the law (Adarkwa and Akyaw 2001: 205). The weak state of planning delivery has contributed to the emergence and 
growth of unplanned settlements, especially in the urban areas. UN-Habitat (2009) for example estimates that 7 in 10 urban dwellers in Ghana are likely to be living in slum like conditions.

The state of land use planning in Ghana is the result of several challenges. These include acute funding shortages for planning activities, weak legislative framework and human resource constraints, logistical challenges and the rent seeking and corrupt attitude on the part of some key stakeholders (for a detailed analysis of the planning challenges see Antwi and Adams, 2003). Other studies (Kasanga et al, 1996; Yeboah and Shaw, 2013) have attributed the poor state of land use planning delivery to the existing land tenure arrangements. Such authors argue that land use planning is a spatial activity, which is influenced by the prevailing land tenure practices. Land tenure practices define the mode of land ownership, use and dispositions among others (Asiama, 2006) whereas land use planning primarily seeks to ensure that land use patterns are consistent with existing framework (Kivell, 1993).

Customary lands constitute an estimated $80 \%$ of lands in Ghana and the main source of land for property development (Kasanga and Kotey, 2001). Dynamics and emerging patterns in customary land tenure arrangements therefore have implications for planning delivery. Evidence (as presented in this paper) indicates that customary trust relations for example is under going rapid re-definition with chiefs and other customary trustees pursuing their parochial interest instead of safeguarding the collective good (Asiama, 2004; Ryan, 2006). Considering that the doctrine of trusteeship is central to customary land tenure practices, any developments could have ramifications for the operation of the formal land use planning system. However, the planning implications for the changing customary land tenure relations have not been explored, and this situation has resulted in a knowledge gap. This paper seeks to contribute towards addressing this gap. As a precursor to this, it is important to situate the research in the context of land holding and land tenure arrangements in Ghana.

\section{Nature of land ownership patterns in Ghana}

Land ownership patterns and tenure categories in contemporary Ghana are significantly nuanced with its colonial past although there are traces of the pre-colonial heritage as well as post-colonial experiences. These experiences have helped to shape land ownership in Ghana into two broad categories. These are public (or state) lands and customary lands. State or public lands refer to all lands that are jointly owned by citizens of Ghana and managed by the Public and Vested Lands Division of the Lands Commission. According to Article 257(1) of the 1992 Constitution, 'all public lands in Ghana shall be vested in the President on behalf of and in trust for, the people of Ghana'. Article 257 (1a) tasks the Lands Commission to manage public lands. The Public and Vested Land Division of the Lands Commission is specifically assigned with the duties of managing public lands under section 23 of the Lands Commission Act, 2008 (Act 767). Lands that were acquired by the colonial authorities but handed over to the state during independence (such as Ridge and Cantonments in Accra) and lands which have been compulsorily acquired in the interest of the state (for example Tema Township and Volta River Development Project) are all examples of state lands.

The second category of land ownership in Ghana is the customary land. These are lands which are collectively owned by families, tribal or ethnic groups. Customary lands may be referred to as skin lands in the northern part of the country or as stool lands in the south. When land is communally owned, each member of the land owning group has a stake in this asset (Kasanga and Kotey, 2001). The principal leader of the land owning group (be it a chief, head of family or head of clan) therefore has the intrinsic responsibility to ensure that the benefits that accrue from the jointly owned resources are equitably distributed or utilized. 
These traditional leaders should therefore hold and manage lands in the interest of the collective good. Effectively, this is a trust arrangement as examined by Watt (2010) and Petit (2012). According to both authors, trust arises when one party holds and manages land for the benefit of another. Watt (2010) and Petit (2012) separately argued that a person who holds a property becomes the trustee whereas a person or a group of individuals who are entitled to use and enjoy the gains from land ownership are the beneficiaries. The property that is being held in trust is known as the trust property or object of trust (Watt, 2010; Petit, 2012). This bears striking semblance with the arrangement under customary land ownership in Ghana. As Danquah (1928: 200) observed:

"The stool occupier [who in most cases is the chiefl ... holds the lands and other stool property in trust for the ancestors (Nsamanfo) and to the benefit of the subjects to the stool"

Indeed this well-established customary arrangement has been recognized and enshrined in the Constitution of Ghana. Article 36(8) of the 1992 Ghanaian Constitution stipulates:

"The state shall recognize that ownership and possession of land carry a social obligation to serve the larger community and, in particular, the state shall recognize that the managers of public, stool, skin and family lands are fiduciaries charged with the obligation to discharge their functions for the benefit respectively of the people of Ghana, of the stool, skin or family concerned, and are accountable as fiduciaries in this regard”.

Both customs and statutes therefore categorize chiefs and other traditional authorities as trustees who are expected to ensure that benefits accruing from collectively owned land are used for the collective good. It must be noted that the relationship between customary tenure dynamics and land use planning practices is empirical in nature. Accordingly, this paper draws from a broad spectrum of empirical evidence. The next section discusses the methodology that was employed for the empirical research.

\section{Selecting the research method}

The objective of the paper, as indicated earlier, is to examine how trusteeship, a fundamental aspect of customary land tenure practices is evolving and impacting on land use planning delivery in contemporary Ghana. Achieving this objective requires an appropriate research methodology. Historically, enquiries of this nature have been conducted through two main methodological and philosophical paradigms: the qualitative and quantitative research methods. However, achieving the objective of this paper requires exploration in order to develop greater insight and appreciation of the issues and therefore the qualitative research method was employed for this study (Creswell, 2003).

\section{Selecting the case study areas}

There are variations in terms of land tenure practices and the spatial characteristics of the northern and southern parts of Ghana as well as between the rural and urban communities (Grant, 2009). Lands in the northern part of the country are primarily skin lands whereas stool land ownership is dominantly prevalent in the south. This variation informed the need to select case study areas from both geographical areas. Four case study areas, which are all local planning authorities, were conveniently selected to reflect these internal variations. In the southern part of Ghana, the Ejisu Juaben Municipality and Kumasi Metropolitan authority were selected to represent the rural/peri-urban and urban planning authorities respectively. The Kumasi Metropolitan Authority undertakes planning functions for the Kumasi traditional area whereas the Ejisu-Juaben Municipal Authority undertakes planning roles for lands which are under the jurisdiction of the Ejisu traditional area.

In the North, the Tamale Metropolitan Authority and the Savelugu Nanton Municipal Assem- 


\section{Yeboah and Oppong}

bly were selected. The planning functions of these areas have been vested in the Tamale Metropolitan and Savelugu-Nanton Municipal Authorities. In line with the Communicative Planning Theory, respondents from both the traditional land owning communities, the formal planning institutions and other allied organisations were engaged. Additional respondents were also purposively selected from allied land use planning institutions at the regional level in the Northern Region. Views and findings from the local and regional levels were further discussed with key stakeholders at the national level. This effort was made to ensure that verified and validated findings are reflective of the situation across Ghana. The field research was conducted from November, 2009 to May, 2013. Fig. 1 shows the location of each of the case study areas within Ghana.

Urban areas in Ghana are largely under intense land pressures as a result of rapidly increasing population (Government of Ghana, 2010). Many peri-urban areas in Ghana are experiencing rapid land use change from agriculture to to property development (Ubink and Quan,

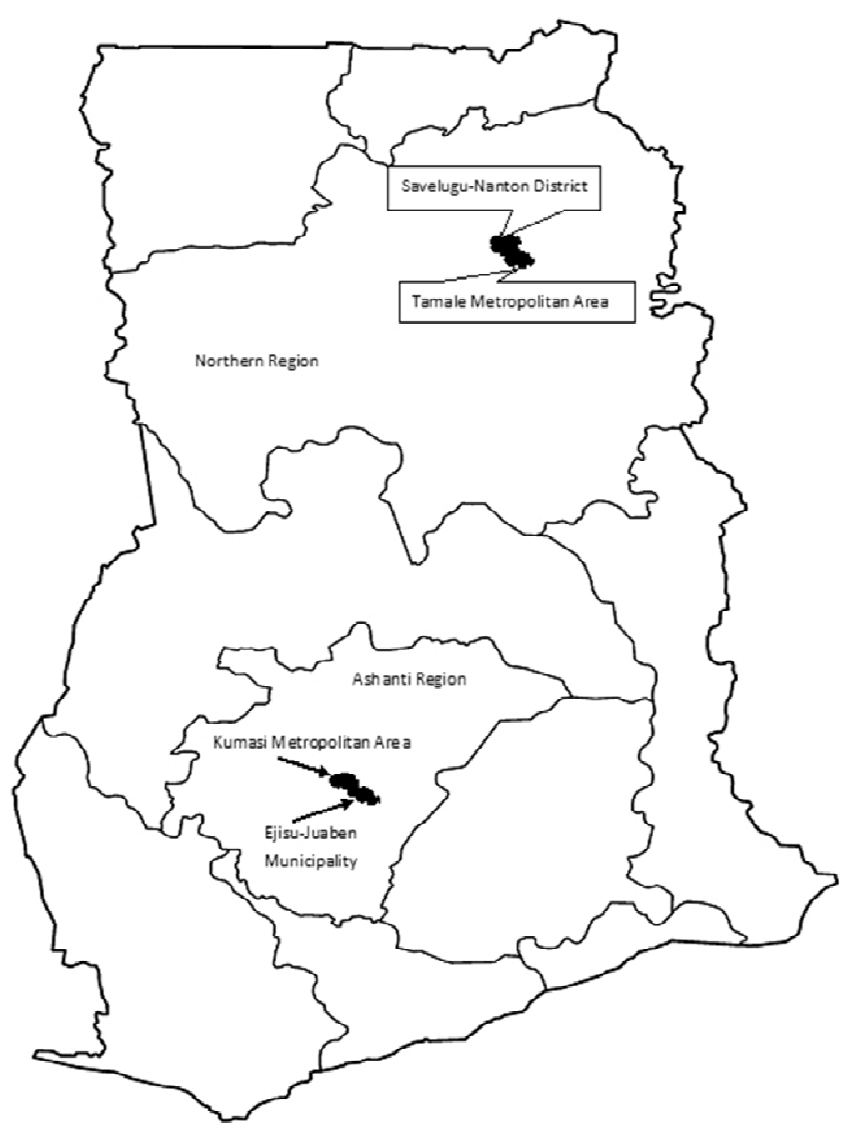

Fig. 1: Map of Ghana showing the case study areas (Source: Adapted from Mapsof.net 2013)

Journal of Science and Technology @ KNUST December 2015 
2008). Lands in Kumasi and Ejisu-Juaben are stool lands whereas lands in Tamale and Savelugu-Nanton are skin lands. The choice of the case study areas therefore provides the opportunity to examine the implications of the customary tenure dynamics from contexts with different population pressures as well as land tenure regimes.

\section{Sampling and techniques for data collection} Conceptually, this study is grounded in the Communicative Planning Theory as propounded by Healey (Healey, 1992). This theory posits that planning is a technical activity which is primarily concerned with negotiating contesting interests over land (Healey, 1992; 1999). The spatial nature of planning makes the issue of land very central in the planning discourse. This is justified because how land is owned, controlled and alienated impact on the shape, layout and growth of urban forms (Kivell, 1993). The communicative planning theory requires that planning is conceptualized as interactive and integrative processes which should initiate and sustain dialogue and build consensus in order to ensure optimal and sustainable land use. In this regard, planning becomes a co-operative action. Drawing from these propositions, the study engaged a range of stakeholders as part of the efforts to improve understanding of the current state of affairs while exploring for pathways to improve planning delivery.

According to section 46 of the Local Government Act, 1993 (Act 462), each district, municipal or metropolitan authority is the designated institution mandated to oversee land use planning delivery. Section 46(3) of the same Act also provides for the establishment of the District Planning Coordinating Unit. The Planning Officer for the local government authority and another member of the district planning coordinating unit were interviewed. Besides interviewing the two people, a focus group discussion involving two local councilors, two traditional leaders and four people who have had recent experiences with the processes involved in obtaining planning permission in the respective areas were organized in each of the four areas. A total of ten key stakeholders in land management and planning delivery were therefore engaged in each of the four case study areas.

Additional respondents were engaged from institutions such as Lands Commission, the Ghana Land Administration Project, Office of the Administrator of Stool Lands and the Town and Country Planning Department both at the regional and national levels. Respondents from the Ashanti and Northern Regional Coordinating Council as well as the National Development Planning Commission were also interviewed. In all, 40 respondents were engaged at the local level. This included an interview with the chief of Ejisu as well as one principal elder. This was replicated in Savelugu. In Kumasi two principal elders who are involved in land related decision making were interviewed at Manhyia. Similarly in the north, two principal elders were engaged in Tamale. At the regional and national levels, 16 and 8 key stakeholders were respectively interviewed. This systematic approach of gathering validated data was designed to ensure that spurious conclusions are avoided. All interviews were transcribed into Microsoft Word and subsequently examined using the Critical Discourse Analysis Technique as defined by Wodak and Meyer (2009).

\section{RESULTS AND DISCUSSIONS}

The study seeks to examine how the doctrine of trusteeship, a central attribute of customary land holdings is currently evolving in response to contemporary pressures. This sets the basis to explore the implications of this changing trend for land use planning delivery. These issues are looked at in the ensuing sections.

\section{Evidence of the changing trust relations in contemporary Ghana}

Trustees are generally obliged to be diligent with what has been entrusted to them in order to safeguard the interest of the beneficiaries 
(Watt, 2010). Another critical duty of trustees is the need for them to be accountable to the beneficiaries (Petit, 2012). However in Ghana, some chiefs have failed to comply with these cardinal principles of trust relations. Motivated by the desire to quickly enrich himself, the chief of Atwima (near Kumasi) for example violated his position as a trustee by alienating the same parcel of land to twelve different people. He was destooled eventually (Otumfuo, 2009). Such examples are so endemic across the country that some traditional leaders have expressed concern. Otumfuo Nana Osei Tutu II -Asantehene (Overlord) of the Asante Kingdom for example has challenged custodians of customary lands to be transparent to their communities (Otumfuo, 2011). Such calls have prompted the National House of Chiefs to come up with a Transparency and Accountability Charter and Code of Ethics to ensure some degree of transparency and accountability in the discharge of the fiduciary roles of chiefs (Nabila, 2012). The call for such self-regulating interventions is an admission by chiefs that some of their colleagues are breaching their positions as trustees.

Some earlier studies have identified this situation where chiefs prioritise the need to enrich themselves from community resources to the detriment of the entire community. Ryan (2006) for example reports that some chiefs and their extended families are pushing for profit from their land, profit which is not necessarily utilized for the benefit of the communities they represent. Indeed the token payment of 'drink' or 'cola' money, which was made in the past to access land has currently evolved into the prevailing open market value of the land to be acquired (Kasanga, et al, 1996). Significantly, money from land granted out to investors and developers may not be used to benefit the broader communities (Ryan, 2006). According to Asiama (2004),

"People have begun to question the fact that chiefs hold the land for the community and yet appear to be the sole beneficiaries of land grants- sometimes to the almost exclusion of the members of the community..... In many cases, chiefs have become the sole beneficiaries while the rest of the community has to live in abject poverty" (Asiama, 2004: 12).

In effect, the ability of traditional authorities to maximize their personal interest from land disposition is a key driving force in making land management decisions.

There are variously reported instances where communities have organized themselves to demand accountability from their traditional leaders who have appropriated community funds for their personal use;

"Scores of people at Nobewam in the Ejisu -Juaben Municipality [have] protested against the alleged indiscriminate sale of their lands by their chief and his failure to account for the proceeds. They accused Nana Adu Gyamfi [the chief] of having sold a number of building plots and [has] pocketed the money from the transaction. They appealed for the Omanhene's [to whom the accused chief is directly accountable] intervention to compel Nana Gyamfi to account for the amounts realized from the land sale. The money, they said, should be used to support the development of the community but not the personal comfort of the chief" (Ghana News Agency, 2010, $17^{\text {th }}$ November)

In a similar development, citizens from Kwamo, a community near Kumasi demonstrated against their chief for embezzling community revenue and failing to render the stool accounts to the people of Kwamo since his enstoolment about 32 years ago (Ghana News Agency, 2005). In their petition, the citizens observed that;

Though they had evidence that the chief had sold about 1000 plots of land for both residential and industrial use, funds accru- 
ing from the sale of these plots of land were yet to be committed into development projects (Ghana News Agency, 2005, 25 ${ }^{\text {th }}$ February).

Similar examples have been observed in the northern part of Ghana (Ghana News Agency, 2011). Although these are only a few examples, they nonetheless give an indication of the general trend in the country. The doctrine of trusteeship, which underpins customary land relations between chiefs and community members is therefore undergoing some redefinition.

What are the implications of the changing trusts relations for land use planning?

By law, district, municipal and metropolitan assemblies are responsible for land use planning for their respective jurisdiction. These local government agencies are therefore tasked with preparing land use plans, altering existing land use plans and ensuring that proposed land uses are compatible with the existing planning framework. However, evidence indicates that chiefs and other custodians of customary lands are executing these mandates often without the knowledge or involvement of the appropriate state agencies.

Land values in the urban and peri-urban areas are rapidly rising as a result of population pressures. Allocating land to prospective developers is therefore a major source of revenue to rent seeking chiefs who redefine the basis of customary trust relations for their parochial gains. In areas where there are existing land use plans, it is a common occurrence for chiefs and other customary land owners to alter such plans by sub dividing and allocating land for uses which are not supported by the prevailing planning framework. The case below is illustrative;

Some concerned citizens of Kwamo in the Ejisu-Juaben District of Ashanti have petitioned the Asantehene, Otumfuo Osei Tutu II, to destool the Kwamohene... The petitioners contended that part of the land in the town demarcated as a cemetery had been sold to people to build residential houses on it. Nana Amoako-Mensah has also sold to private developers, a piece of land allocated and reserved for Obrempong Tano, Asanie Kyere and Akonodi Shrines, whilst the land reserved alongside streams at Kwamo, especially Bodiwaa, Boadaa, Saman and Asuoadwoa have been sold to private developers who have virtually built in the beds of the stream (Ghana News Agency, 2005, 24 February)

In the above example, the existing planning framework that allocated the land for cemetery and reserved lands along the rivers, has been unilaterally altered by the chief. Such activities distort the existing plan for the area as well as heightening the risk of flooding as a result of people building along water courses. This practice of unilateral alteration of land use plans by chiefs was corroborated by several respondents. A respondent from the Town and Country Planning Department in Ejisu noted that;

"Land allocated for building new schools are now being converted to developing shops... Areas which have been allocated for building new hospitals and clinics are been converted to private housing development... Development in many areas, especially in the peri-urban hardly reflect anything that is contained in the plan... because chiefs always sell land for unauthorized land uses".

It is worth noting that such actions to sub divide and allocate for residential housing development is motivated by the desire to maximize financial gains by the chief as a result of the changing trust relations. In Kumasi, a respondent from the Lands Commission outlined a litany of instances where existing land use plans have been unilaterally sub-divided by chiefs for the purpose of allocating land for uses that may not necessarily conform to the existing planning framework. He noted that such practices are particularly common in the Kumasi Metropolitan Authority with areas such 
as Apire (near Santasi), Aprade and Fumesua being examples.

Chiefs and other traditional leaders who were engaged as respondents for the study also admitted that it is a common practice for some of them to alter existing land use plans. The view of a traditional leader in Savelugu further reinforced the earlier observations by the state officials. He noted that;

Even when plans have been prepared for their areas, some of them still insist on allocating land in a way and manner that may not be consistent with what has been proposed by the planning authorities

This admission was corroborated by traditional leaders in Kumasi, Tamale and Ejisu. Under such circumstances, it is difficult to ensure that developments proceed according to plan.

The above developments where chiefs unilaterally alter existing land use plans often with the help of unprofessional planners and surveyors are worrying, just like the case of unilateral preparation of unsuitable 'plans' as the basis for human settlement planning.

It is a common practice for chiefs to engage self-styled planners to prepare 'plans'. As a result, what is produced as the plan to guide the growth of towns and cities are often substandard and lack almost all the attributes of an actual land use plan. The description of these 'plans' by an official from the Town and Country Planning Department (Savelugu-Nanton Municipal Planning Office) highlights how illfitted these 'plans' are:

"What chiefs call plan is not something you and I would want to call a plan. What they do is that, they tell a quack planner or surveyor that they [the chiefs] want for example $X$ number of building plots in every acre of land. So what the so-called planners do is to demarcate the land to get $X$ plots in every acre. That is all about it. There are no ingredients of planning in there at all"
Chiefs are increasingly becoming rent seeking. Asiama (2004) argues that one way to check this trend is through the active involvement of the state agencies in the land demarcation and allocation process. The chiefs circumvent due process in order to avoid resistance with respect to allocating land for their financial benefits. Under such circumstances, haphazardly laid out settlements without adequate supply of services is inevitable. As a respondent from the Town and Country Planning in Tamale noted:

"In most cases, we go to communities where plans are to be prepared only to be confronted with already growing settlements which in most cases have no access roads, no parks and no hospital. This is what our chiefs contract people to do... So clearly it becomes more difficult to prepare plans because you have to correct the existing errors committed by the so called surveyors"

Some chiefs and other custodians of customary lands who were engaged noted that it is within their right to ensure that plans are prepared for their respective areas. Respondent 9, a chief from Ejisu noted that;

The land is ours and the government only helps us to plan for its use. If they [the state institutions] are unable to undertake their planning responsibilities, we cannot look unconcerned. We have to step in and find possible ways of dealing with the growing human settlement.

In principle the state institutions are not against what could be complementary efforts from chiefs to support planning delivery in Ghana. Indeed in several peri-urban communities, some chiefs have taken the initiative to collaborate with the appropriate state agencies to prepare plans to guide the growth of the areas (Kasanga et al, 1996). This is a welcoming development. The involvement of the chiefs in the planning process becomes problematic when with the aid of unprofessional people, 
they cause substandard plans to be prepared to misguide the expansion of human settlements.

Some key enforcement challenges in the Ghanaian planning system

Under section 2(I) of the Town and Country Planning Ordinance, 1945 (Cap 84), only the Minister responsible for land use planning has the power to declare places as planning areas after consultations. After such declaration, section 46(I) vests all planning powers in the appropriate local planning authority. Chiefs and other custodians of customary land therefore in principle do not have the power to unilaterally prepare land use plans. As a result, chiefs are expected to work in close collaboration with the planning authorities particularly when such customary leaders are taking the initiative to prepare land use plans for their respective areas.

The foregoing discussions highlight that, it is a common occurrence within the case study areas that chiefs alter existing land use planning framework by sub dividing land and allocating it for uses which are often not supported by the existing land use plan. This is in direct contravention of section 61 (I) of the Local Government Act 1993 (Act 462), which provides that;

An allocation of land is void if the purpose or use for which the allocation is made is contrary to a provision of an approved development plan; and in particular, a landowner shall not subdivide or allocate a land for use, development or occupation in a town or city or in the suburb of it or in an area where there is an approved planning scheme prepared under an enactment.

Section 62(2) of the Local Government Act, 1993 (Act 462) further provides that;

A person who allocates, transfers, sells or develops land for a use or a purpose that is contrary to an approved development plan, settlement structure plan, action plan or programme commits an offence and is lia- liable on conviction to a fine not exceeding two hundred penalty units or to a term of imprisonment not exceeding six months or to both the fine and the imprisonment.

Despite these provisions, chiefs and other custodians of customary lands often prepare land use plans or alter existing ones without reference to the designated planning authorities. Such unilateral actions should attract the stipulated sanctions under the Act. However, evidence from the four case study areas, two regional authorities and the various national stakeholders indicated that chiefs and other people who engage in unauthorized allocation of land to prospective developers are hardly ever sanctioned. In effect, custodians of customary land are continuously breaching laws relating to land use planning in the country with impunity.

But why are the stated sanctions not applied to those who are in continuous breach of the laws? Challenges such as human resource shortages and logistical constraints have earlier been examined by (Yeboah and Shaw, 2013). This study reports that there is a ratio of about 1 planner: 600,000 persons in the country. This has created the situation where one planner may be responsible for the planning activities in several planning areas. Such situations can undermine efficiency considering that many aspects of the planning process are based on hardcopy and driven by manual systems and not modern technology.

Further investigations brought to the fore that, two other issues are a major setback to the planning process. First, political interference and manipulation of the planning process are major hindrances to the enforcement of planning laws and regulations. In Ghana however, the planning process has often been manipulated by political players often for electoral gains. The District Chief Executive for the Savelugu Nanton District noted that:

As a politician, you have to be at peace 
with all key stakeholders in your area at all times. I admit the attitude of most chiefs does not allow planning to proceed on any sound basis but it will be politically immature, if not suicidal to be engaging in legal tussles with chiefs because of land they have allocated.

Other respondents noted that some planning decisions could result in some short-term dissatisfaction from people although such decisions could inure to the collective benefit in the future. However, the political authorities are often categorical that 'they are not prepared to make neither themselves nor their political party unpopular by enforcing such planning prescriptions' (Respondent 22, from Town and Country Planning Department, Tamale). The view of Respondent 8, an official from the Town and Country Planning Department in Kumasi helps to further put this in context:

The politicians are only motivated by the desire to win or retain power, which is a matter of vote. A nicely planned neighbourhood does not vote but people who live in unapproved developments [if they are 18 years or above] do. How can you get the backing of the politicians to sanction chiefs if such decision will have adverse effect on their political fortunes?

There are times where some local government authorities have attempted to enforce existing planning regulations that may be considered politically unpopular. The case of the demolishing of unapproved developments in Sodom and Gomorrah, a rapidly growing slum in Accra, is illustrative. When the City Authorities planned to embark on the planned demolishing exercise in 2009, residents in the area threaten to defect en bloc from the ruling National Democratic Congress to the opposition New Patriotic Party. The residents asked the political leaders whether they did not know the place was a slum when they were seeking their votes (Gobah, 2009). This threat drew a quick intervention from the then President. He ordered the
City Mayor and other stakeholders to;

\begin{abstract}
Suspend the decongestion exercise and treat the people with a human face [adding that]........when we are working to improve the economy, it is not proper for us to treat our people in this manner (Gobah, 2009, p. 1)
\end{abstract}

Political considerations therefore in many instances prevent the implantation and enforcement of planning laws.

The issue of power imbalance which exists between chiefs, the planning authorities and other stakeholders is also another cause of the apparent lack of enforcement against chiefs who breach planning regulations. Chiefs and traditional authorities wield considerable power under the present socio cultural dispensation. Under customary arrangement, the chiefs are regarded as "fathers" to all residents within their areas of jurisdiction. Residents who are indigenes double as subjects of the stool/skin who owe allegiance to the chief. The concept of subjectship means the chiefs are empowered to issue commands which others are enjoined to obey in order to avoid the threat of punishment (Shively, 2001 cited in Njoh, 2006). This power differential has effectively elevated chiefs to the status of 'untouchables'. Admittedly, there are isolated instances where chiefs have been found culpable and jailed in Ghana (Daily Guide, 2012). However, this represents the exception rather than the rule. Evidence indicates this socio-cultural arrangement has often disempowered authorities from sanctioning chiefs and other custodians of customary lands.

The various respondents, especially the planning officers at the local level indicated that imbalance in power relations between planning officials and chiefs poses a challenge in terms of strict enforcement of planning regulations. Respondent '7' a planning officer in Ejisu observed that;

Our chiefs sell land for uses that they 
Improving land use planning delivery in Ghana ... 70

should not. How can you sell every inch of land for development? As a state institution, we have the legal backing to push our plans through [to implementation]. But you have to balance it with the fact that you are dealing with chiefs who are our fathers [under customs]... Our chiefs are real source of issue for us.

This observation was further corroborated by other planning officers, chiefs and other stakeholders. This situation is consistent with the assertion by Flyvberg (1998) that in the face of power and technical rationality, technicalities always yield to power. The imbalance of power relations between chiefs and state officials together with political interference, weak legislative framework, human resource and logistical constraints jointly hinder enforcement of planning laws and regulations and this eventually contribute to poor planning delivery.

\section{RECOMMENDATIONS AND CONCLU- SION}

Planning failure in Ghana results from a plethora of factors such as institutional and legal weaknesses, logistical constraints, weak enforcement and rent seeking behavior on the part of some land based professionals. Drawing from empirical evidence, this paper has critically examined one of the underlining causes of the poor state of land use planning delivery and established that, the changing trust relations which allows chiefs and other elites to become the principal beneficiaries of proceeds from land allocation is a major factor contributing to the poor state of planning delivery in Ghana.

Attempts to improve the state of planning delivery in Ghana require a holistic approach as espoused in the communicative planning theory. Such efforts should aim at streamlining the legislative framework for formal land use planning delivery as well as exploring for models for self-financing planning activities in a sustainable manner. A self-financing planning system could minimize dependence on local and central government for logistical support.
A planning systems that is financially independent from local and central government could help to minimize the extent of political interference and manipulation of the planning process. Furthermore, building the capacity of planning officials to effectively deal with the issue of imbalanced power relations could also be crucial in instilling some level of sanity in the operation of the planning systems.

Finally, empowering communities to demand transparency and accountability in the use of revenue accruing from the sale of land is a useful first step. Downward social accountability could ensure that chiefs do not remain the principal beneficiaries of land based revenue. Such intervention could help to preserve the original arrangement of trusteeship under customary tenure, which seeks to secure the interest of the beneficiaries. These thoughts could strengthen the framework for planning to achieve its goals of effectively guiding the growth of human settlement in an orderly, convenient and aesthetically acceptable manner.

\section{REFERENCES}

Adarkwa, K. K. and Akyaw, O. (2001). Development Control in Kumasi, in The Fate of the Tree, Planning and Managing the Development of Kumasi, by Adarkwa, K. K. and J, Post (ed), J, Woeli Publishing Services, Accra

Antwi, A. Y. and Adams, Y. (2003). Rentseeking Behaviour and its Economic Costs in Urban Land Transactions in Accra, Ghana Urban Studies,40(10): 2083-2098

Asiama, S. O. (2006). Colonialism and the Modern State: Land Tenure Relations in Sierra Leone. Africa, LXI (2):219-237.

Asiama, S. O. (2004). "Current Changes in customary/traditional land delivery systems in sub Saharan African cities, case study of Kumasi”, Paper presented at International Workshop on Land for Housing in African Cities. Graduate School of Public and Devel- 


\section{$71 \quad$ Yeboah and Oppong}

opment Management, Johannesburg, South Africa, February 16-20, 2004.

Creswell, J. (2003). Research Design: Qualitative and Quantitative Approaches. Thousand Oaks, CA, Sage.

Daily Guide (2012). Elmina Chief Jailed, Accessed on 16/07/2013 from http:// www.ghanaweb.com/GhanaHomePage/ NewsArchive/artikel.php?ID=236128

Danquah, J. B. (1928). Akan Laws and Customs and the Akim Abuakwa Constitution. Oxford University Press, Oxford.

Flyvbjerg, B. (1998). Rationality and Power Democracy in Practice Chicago and London: The University of Chicago Press.

Ghana News Agency (2005). Concern citizens of Kwamo petition Asantehene. http:// www.modernghana.com/news/72597/1/ concern-citizens-of-kwamo-petitionasantehene.html)[Accessed on 24/6/2013]

Ghana News Agency (2010). People of Nobewam up in arms against chief. http:// www.ghanaweb.com/GhanaHomePage/ News Archive/artikel.php?ID=197630. [Accessed 24/6/2013]

Ghana News Agency (2011). Minister worried about indiscipline, lawlessness in Tamale $\begin{array}{llllllllllllllllll}M & \mathrm{e} & \mathrm{t} & \mathrm{r} & \mathrm{o} & \mathrm{p} & \mathrm{o} & \mathrm{l} & \mathrm{i} & \mathrm{s} & \text {. } & \mathrm{h} & \mathrm{t} & \mathrm{t} & \mathrm{p} & : & \mathrm{l} & /\end{array}$ www.ghananewsagency.org/details/Social/ Minister-worried-about-indisciplinelawlessness-in-Tamale-Metropolis/? ci=4\&ai=30556 [Accessed 24/6/2013]

Gobah, T. (2009). Suspend demolishing exercise. President directs Accra Metropolitan Assembly, Daily Graphic No. 18106, Accra

Grant, R. (2009). Globalizing City, the urban and economic transformation of Accra, Ghana. Syracuse University Press, New York.
Healey, P. (1999). Institutionalist Analysis, Communicative Planning, and Shaping Places, Journal of Planning Education and Research, 19: 111-121

Healey, P. (1992). Planning through debate. The communicative turn in planning theory, Town Planning Review, 63(2): 143-162

Kasanga, K. and Kotey, N. A. (2001). Land Management in Ghana: Building on Tradition and Modernity. IIED, London.

Kasanga, R. K., Cochrane, J., King, R. and Roth, M. (1996). Land markets and legal contradictions in the peri-urban area of Accra, Ghana: Land Tenure Centre, University of Wisconsin-Madison/Land Administration Research Centre, University of Science and Technology, Kumasi

Kivell, P. (1993). Land and the City; Patterns and processes of urban change, Routledge, London and New York.

Nabila, J. (2012). Code of ethics to regulate activities of chiefs in the offing, accessed from http://edition.myjoyonline.com/pages/ news/201208/92245.php on 20/9/14

Government of Ghana (2010). National Urban Policy. Ministry of Local Government and Rural Development, Accra.

Njoh, A. J. (2006). Planning Power: Town Planning and Social Control in Colonial Africa. UCL Press, London.

Otumfuo, O. T. (2011). Chiefs should be transparent and accountable. http:// ghananewsagency.org/social/chiefs-shouldbe-transparent-and-accountable-asantehene36962 [Accessed 12 May 2013]

Otumfuo, O. T. (2009) Otumfuo Destools Chief over multiple land sales. http:// ghanapundit.blogspot.com/2009/11/otumfuodestools-chief-over-multiple.html [accessed 
Improving land use planning delivery in Ghana ... 72

on $20 / 9 / 14]$

Petit, P. H. (2012). Equity and the Law of Trusts. Oxford University Press, Oxford.

Ratcliffe, J. and Stubbs, M. (1996). Urban planning and Real Estate Development. UCL Press, London.

Ryan, O. (2006). Ghana Chiefs' Land Rows Spook Investors. Accessed from http:// news.bbc.co.uk/2/hi/business/4754331.stm on $12 / 9 / 14$

Ubink, J. M. and Quan, J. F. (2008). How to Combine Tradition and Modernity. Regulating Customary Land Management in Ghana, Land Use Policy, 25: 198-213

UN-DESA, (2013). Africa: Population esti- mates and Projections, [accessed from http:// esa.un.org/unup/unup/p2k0data.asp) on $16 / 7 / 2013$ ]

UN-HABITAT, (2009). State of the World's Cities. UN-HABITAT, Nairobi.

Watt, G. (2010). Trusts and Equity. Oxford University Press, Oxford.

Wodak, R. and Meyer, M. (2009). Methods of Critical Discourse Analysis. Sage, New York.

Yeboah, E. and Shaw, P. D. (2013). "Customary land tenure practices in Ghana: examining the relationship with land-use planning delivery". International Development Planning Review, 35: 21-39. 